\title{
Effect of cultivar and formaldehyde treatment of barley grain on rumen fermentation characteristics using in vitro gas production
}

\author{
M. Colkesen ${ }^{1}$, A. Kamalak ${ }^{2 \#}$, O. Canbolat ${ }^{3}$, Y. Gurbuz ${ }^{2}$ and C.O. Ozkan ${ }^{2}$ \\ ${ }^{1}$ Kahramanmaras Sutcu Imam University, Faculty of Agriculture, Department of Crop Science and \\ ${ }^{2}$ Kahramanmaras Sutcu Imam University, Faculty of Agriculture, Department of Animal Nutrition \\ 46100 Kahramanmaras, Turkey \\ ${ }^{3}$ Bursa Uludag University, Faculty of Agriculture, Department of Animal Nutrition, Bursa, Turkey \\ 46100 Kahramanmaras, Turkey
}

\begin{abstract}
The aim of this study was to determine the effects of cultivar and formaldehyde treatment of barley grains on rumen fermentation characteristics using the in vitro gas production technique. Amount of gas produced $(\mathrm{mL} / \mathrm{g}$ organic matter $(\mathrm{OM}))$ during fermentation was determined after $0,3,6,12,24,48,72$ and $96 \mathrm{~h}$ of incubation in buffered rumen fluid. The gas production kinetics were described using the equation: $y=A\{1-\exp [-b(t-T)-c(\sqrt{ } t-\sqrt{ } T)]\}$ where $b$ and $c$ are the initial gas production rate constant $\left(\mathrm{h}^{-1}\right)$ and later gas production rate constant $\left(\mathrm{h}^{-1 / 2}\right)$, respectively. Cultivar and formaldehyde treatment had significant effects on gas production kinetics. Total gas production $(A)$ ranged from 389.9 to $410.8(\mathrm{~mL} / \mathrm{g} \mathrm{OM})$ with the cultivar, Esterel, producing the largest volume of gas of the cultivars. Due to low gas production rates at 3, 6 and $12 \mathrm{~h}$ of incubation the cultivars, Viva and Cecilla, took the longest to produce $50 \%$ of their total volume of gas. Formaldehyde treatment reduced the rate $(\mu)$ of gas production at 3,6 and $12 \mathrm{~h}$ of incubation, and the total volume of gas $(A)$, but increased the time (h) to produce $50 \%$ of $A$ and reduced the time (h) to produce $95 \%$ of $A$. The reduction in gas production ranged from 33.3 to $51 \mathrm{~mL} / \mathrm{g}$ OM with $6 \mathrm{~h}$ incubation showing the highest decrease in gas production. It is concluded that formaldehyde treatment may provide an opportunity to manipulate the site of digestion of barley grain in the digestive tract of ruminants. Through the selection of suitable cultivars and through formaldehyde treatment the nutritional and health problems associated with the fermentation of barley grain in the rumen could be reduced.
\end{abstract}

Keywords: Barley cultivars, formaldehyde treatment, gas production kinetics

${ }^{\#}$ Corresponding author. E-mail: akamalak@ksu.edu.tr

\section{Introduction}

Barley grain is a principal source of energy in small ruminant diets in many parts of world. The introduction of new barley cultivars has resulted in raw materials with a wide range of nutritional characteristics. The rapid rate of fermentation of barley starch contributes to some nutritional and health problems such as reduced feed intake, laminitis, bloat, acidosis, ruminitis and liver abscesses (Ørskov, 1986; Givens et al., 1993). Approximately $80-90 \%$ of barley starch is fermented in the rumen compared to between 55 and 70\% for sorghum and maize (Nocek \& Tamminga, 1991). Differences in the chemical composition of barley cultivars have been reported as well as significant differences in the composition of the protein matrix in the starchy endosperm of the grain. Therefore, these differences might be expected to influence its degradability in the rumen. However, little variation was observed in the ruminal digestion characteristics of Iranian barley grain cultivars using the in situ nylon bag technique (Ghorbani \& HadjHussaini, 2002).

Treatment with formaldehyde ( $\mathrm{HCHO}$ ) has been used for a number of years to protect protein from rumen degradation (Faichney \& Davies, 1973). There is evidence that HCHO treatment may protect the starch components of cereals against rumen degradation (Fluharty \& Loerch, 1989), and HCHO treatment was found to reduce the in situ dry matter (DM) degradation of barley in the rumen (Ortega-Cerrilla et al., 1999a).

In vitro gas production is a method that detects small differences in nutritional characteristics between feedstuffs, allows for more frequent sampling than with in vitro digestibility, and is rapid and precise (DePeters et al., 2003). In assessing the genetic improvement achieved through selection, the gas production 
method was used to provide information on DM and starch digestibility of different sorghum cultivars (Pedersen et al., 2000). The gas production method was also used to compare sorghum grain hybrids that differed in endosperm colour (Streeter et al., 1993) and to evaluate the effects of varieties, growing sites and grain species (Opatpatanakit et al., 1994).

The aim of this study was to determine the effect of cultivars and $\mathrm{HCHO}$ treatment on gas production kinetics of eight cultivars of barley grain.

\section{Materials and Methods}

Eight barley cultivars were sown at a seeding rate of $200 \mathrm{~kg} / \mathrm{ha}$ in triplicate plots $(1.2 \mathrm{~m} \mathrm{x} 5 \mathrm{~m})$ at the Kahramanmaras Agricultural Research Station, Turkey, in November 2002. The area is located at an altitude of $630 \mathrm{~m}$. The mean annual rainfall and temperature are $606 \mathrm{~mm}$ and $17{ }^{\circ} \mathrm{C}$, respectively. The centre is characterized by sandy-clay soils. Nitrogen (N) fertilizer was applied at a rate of $60 \mathrm{~kg} / \mathrm{ha}$ during sowing and second applications of $\mathrm{N}$ and phosphorus fertilizers were applied at a rate of $60 \mathrm{~kg} / \mathrm{ha}$ in February. The plots were not irrigated and moisture supply depended on rainfall. The barley was hand-harvested in the first week of June and the grain was obtained using a threshing machine. A representative sample of the grain from each of the three plots per cultivar was collected for subsequent analyses.

The grain was ground to pass through a $1 \mathrm{~mm}$ sieve for chemical analysis and in vitro gas production. To determine the effect of $\mathrm{HCHO}$ treatment, ground samples from each cultivar were treated with $\mathrm{HCHO}$ by spraying the barley evenly with a HCHO solution $(18 \mathrm{~g} \mathrm{HCHO} / \mathrm{L})$ at a rate of $30 \mathrm{~g} \mathrm{HCHO} / \mathrm{kg}$ of crude protein (CP) (Ortega-Cerrilla et al., 1999b). The treated barley was allowed to dry at room temperature for $24 \mathrm{~h}$ and was stored at room temperature pending the in vitro gas production study.

Dry matter was determined by drying the samples at $105^{\circ} \mathrm{C}$ overnight, and ash by igniting the samples in a muffle furnace at $525{ }^{\circ} \mathrm{C}$ for $8 \mathrm{~h}$. The $\mathrm{N}$ content was measured by the Kjeldahl method (AOAC, 1990) and $\mathrm{CP}$ was calculated as $\mathrm{N} \times$ 6.25. The neutral detergent fibre (NDF) content of the samples was determined by the method of Van Soest et al. (1991), using alpha amylase and sodium sulphite as reagents. The acid detergent fibre (ADF) content was measured following the method of Van Soest et al. (1963). Both NDF and ADF values were expressed without residual ash. Ether extract (EE) was determined by the method of AOAC (1990). Starch content was determined by the Ewers polarimetric method EEC (1972). All chemical analyses were carried out in duplicate.

The treated and untreated dry samples $(0.2 \mathrm{~g})$ were incubated in triplicate in rumen fluid in $100 \mathrm{~mL}$ calibrated glass syringes to measure in vitro gas production, following the procedure of Menke \& Steingass (1988). Rumen fluid was obtained from three fistulated sheep fed twice daily on a diet containing lucerne hay $(60 \%)$ and a concentrate $(40 \%)$ consisting of barley grain. The syringes were prewarmed to $39^{\circ} \mathrm{C}$ before an injection of $30 \mathrm{~mL}$ of a rumen fluid-buffer mixture (in a 1:2 ratio) into each syringe, followed by incubation in a water bath at $39^{\circ} \mathrm{C}$. The syringes were gently shaken $30 \mathrm{~min}$ after the start of incubation and every hour thereafter for the first $10 \mathrm{~h}$ of incubation. Readings of volume of gas produced were recorded before incubation (0) and after 3, 6, 12, 24, 48, 72 and $96 \mathrm{~h}$ of incubation. Total gas volumes were corrected for a blank incubation which contained only the buffered rumen fluid without any barley samples.

Cumulative gas production data were fitted to the model of France et al. (1993) using the MLP (Most Likelihood Program) (Ross, 1987): $y=A\{1-\exp [-b(t-T)-c(\sqrt{ } t-\sqrt{ } T)]\}$ where $y$ represents the cumulative gas production $(\mathrm{mL}), t$ the incubation time $(\mathrm{h}), A$ the asymptote (total gas production, $\mathrm{mL}$ ), $T$ the lag time $(\mathrm{h})$ and $b$ and $c$ the initial and later gas production rate constants $\left(\mathrm{h}^{-1}\right)$ and $\left(\mathrm{h}^{-1 / 2}\right)$. Estimated values of four parameters, $A, T, b$ and $c$ were determined from a time course experiment of $96 \mathrm{~h}$ incubation. The model postulates that the fractional degradation rate $\left(\mu, \mathrm{h}^{-1}\right)$ was not constant, but varies with time along the fermentation period: $\mu=b+c /(2 \sqrt{ } t) ; t \geq T$. Therefore the gas production rates $\left(\mu, \mathrm{h}^{-1}\right)$ at 3,6 and $12 \mathrm{~h}$ of incubation were calculated. The Chi-square test was used to determine how well the gas production data fitted to the model of France et al. (1993).

Analysis of variance (ANOVA) was carried out to compare chemical composition with cultivars as the main factor, using the General Linear Model (GLM) of Statistica for Windows (1993). Two-way analysis of variance (ANOVA) was carried out to determine the effect of cultivars and formaldehyde treatment on in vitro gas production kinetics and their interaction, using the General Linear Model (GLM) of Statistica for Windows (1993). Significance differences between individual means were identified using the Tukey's 
multiple range test (Pearse \& Hartley, 1966). Mean differences were considered significant at $\mathrm{P}<0.05$. Standard errors of means were calculated from the residual mean square in the analysis of variance.

\section{Results}

The chemical composition of the barley cultivars is presented in Table 1. Generally, there were significant differences between cultivars in terms of $\mathrm{CP}$, NDF and starch concentrations. The CP levels ranged from 122.2 to $159.2 \mathrm{~g} / \mathrm{kg} \mathrm{DM}$. The $\mathrm{CP}$ content of cultivar, Angora, was higher $(\mathrm{P}<0.001)$ than that of the others, except for cultivar, Hega. The NDF content ranged from 162 to $187.6 \mathrm{~g} / \mathrm{kg}$ DM with Esterel having the lowest NDF level. The level of starch in the cultivars ranged from 619.2 to $644.5 \mathrm{~g} / \mathrm{kg} \mathrm{DM}$, with that of Angora higher $(\mathrm{P}<0.001)$ than the others, except for cultivars, Hega and Vanesa.

Table 1 Chemical composition $(\mathrm{g} / \mathrm{kg})$ of barley grain of eight different cultivars $(\mathrm{n}=2 /$ cultivar)

\begin{tabular}{|c|c|c|c|c|c|c|c|}
\hline \multirow[b]{2}{*}{ Cultivars } & \multicolumn{7}{|c|}{ Constituents } \\
\hline & $\mathrm{DM}$ & $\mathrm{CP}$ & $\mathrm{EE}$ & NDF & ADF & Starch & Ash \\
\hline Hega & 975.1 & $152.5^{\mathrm{cd}}$ & 23.2 & $178.6^{\mathrm{ab}}$ & 78.5 & $633.1^{\text {bcd }}$ & 25.4 \\
\hline Prosa & 972.5 & $122.2^{\mathrm{a}}$ & 24.0 & $172.1^{\mathrm{ab}}$ & 74.2 & $626.0^{\mathrm{ab}}$ & 25.9 \\
\hline Vanesa & 973.1 & $144.6^{\mathrm{bc}}$ & 19.1 & $187.6^{\mathrm{b}}$ & 65.5 & $640.2^{\mathrm{cd}}$ & 25.0 \\
\hline Viva & 978.2 & $142.5^{b c}$ & 18.9 & $176.4^{\mathrm{ab}}$ & 71.3 & $632.3^{b c}$ & 24.9 \\
\hline $5-8602$ & 959.8 & $143.9^{b c}$ & 28.6 & $184.1^{\mathrm{ab}}$ & 71.0 & $629.5^{\mathrm{abc}}$ & 20.9 \\
\hline Cecilla & 954.2 & $135.4^{\mathrm{b}}$ & 28.4 & $180.2^{\mathrm{ab}}$ & 68.5 & $626.5^{\mathrm{ab}}$ & 24.8 \\
\hline Esterel & 974.7 & $150.6^{\mathrm{cd}}$ & 26.4 & $162.0^{\mathrm{a}}$ & 63.0 & $619.2^{\mathrm{a}}$ & 25.3 \\
\hline Angora & 975.5 & $159.2^{\mathrm{d}}$ & 29.4 & $171.2^{\mathrm{ab}}$ & 67.5 & $644.5^{\mathrm{d}}$ & 24.4 \\
\hline s.e.m & 9.3 & 2.0 & 1.9 & 4.1 & 2.8 & 2.1 & 1.4 \\
\hline $\mathrm{P}$ & NS & $* * *$ & NS & $*$ & NS & $* * *$ & NS \\
\hline
\end{tabular}

DM - dry matter; CP - crude protein; EE - ether extract; NDF - neutral detergent fibre; ADF - acid detergent fibre Means within a column with differing superscripts are significantly different: $* \mathrm{P}<0.05 ; * * * \mathrm{P}<0.001$; NS - Non significant $(\mathrm{P}>0.05)$; s.e.m. - standard error mean

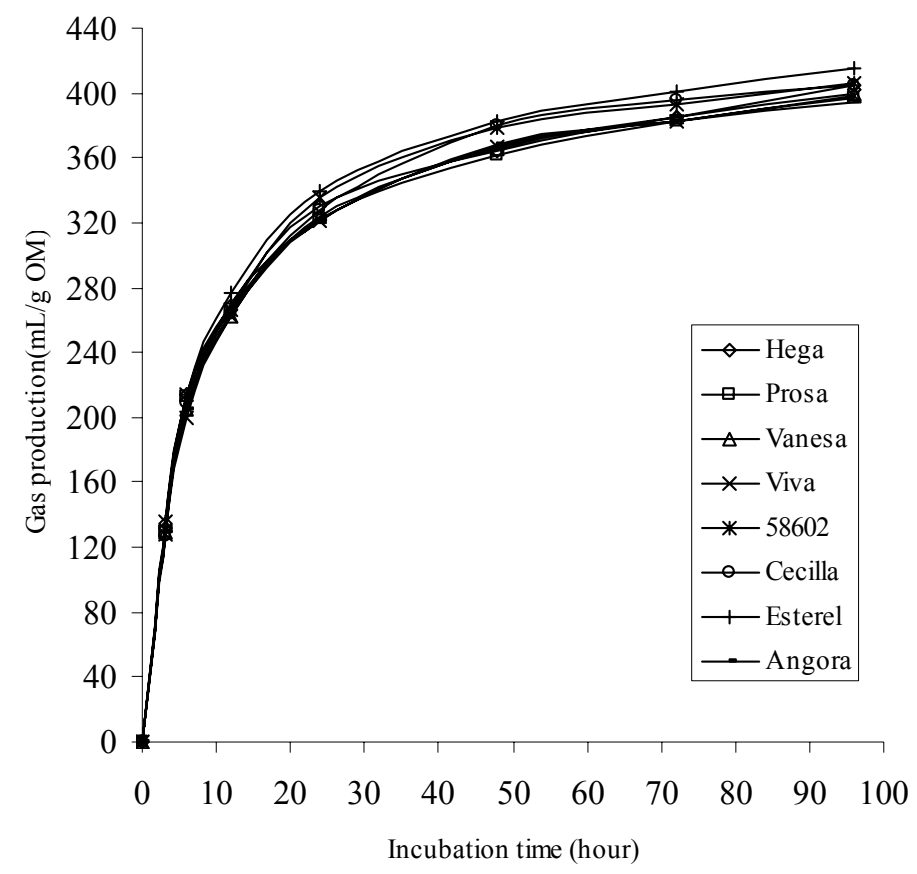

Figure 1 The effect of cultivar on the gas production from barley grain when incubated with rumen fluid 
The volume of gas produced $(\mathrm{mL} / \mathrm{g} \mathrm{OM})$ during the early stages of incubation was similar for all barley cultivars (Figure 1). After $24 \mathrm{~h}$ of incubation the gas production indicated differences between the cultivars, especially Esterel, which showed a considerably higher $(\mathrm{P}<0.001)$ gas production than the other cultivars.

The effect of HCHO treatment on the gas production is presented in Figure 2. HCHO treatment decreased ( $\mathrm{P}<0.001)$ the gas production, ranging from 33.3 to $51 \mathrm{~mL} / \mathrm{g}$ OM for the different cultivars. The average decrease in gas production after $3 \mathrm{~h}$ of incubation was $20.1 \%$ lower than that at $6 \mathrm{~h}$ of incubation.

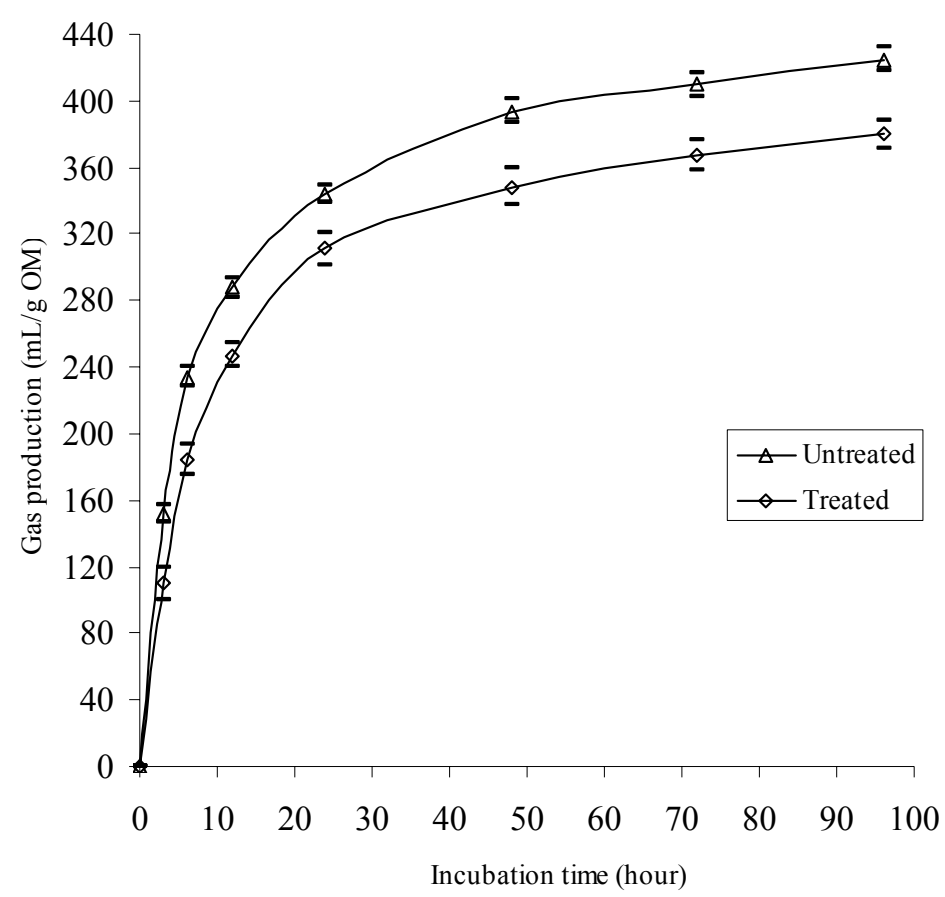

Figure 2 The effect of formaldehyde treatment on the gas production from barley grain (averages for all eight cultivars) when incubated with rumen fluid

The gas production data obtained after different periods of incubation fitted well $\left(\chi^{2}=0.727<\chi_{(\mathbf{1 5}, \mathbf{0 . 0 1})}\right.$ $=30.58)$ to the model reported by France et al. (1993). The estimated parameters of gas production are given in Table 2. Cultivar and HCHO treatment had significant $(\mathrm{P}<0.001)$ effects on gas production kinetics. The lag time for all barley grains was very low and close to zero, and therefore not included in Table 2 . Total gas production ranged from 389.9 to $410.8 \mathrm{~mL} / \mathrm{g}$ OM with cultivar, Esterel, having the highest gas production of the cultivars tested.

The duration (in $\mathrm{h})$ to produce $95 \%$ of the gas was longer $(\mathrm{P}<0.05)$ for cultivars, Viva and Cecilla, than for Hega, Prosa and Vanesa. The time (h) to produce $95 \%$ of total gas from the fermentation of Hega was longer $(\mathrm{P}<0.001)$ than for Angora.

The model postulates that the fractional degradation rate $\left(\mu, \mathrm{h}^{-1}\right)$ is not constant, but varies with time along the fermentation period. As can be seen from Table 2 the rate of gas production $(\mu)$ of all cultivars decreased as incubation time progressed. There were significant differences between the cultivars in terms of rate of gas production $(\mu)$ after 3, 6 and $12 \mathrm{~h}$ of incubation. Among the cultivars, Hega had the highest gas production rate $(\mu)$ after 3,6 and $12 \mathrm{~h}$ of incubation.

The HCHO treatment also had significant effects on the gas production kinetics. HCHO treatment reduced $(\mathrm{P}<0.001) A$, whereas HCHO treatment increased $(\mathrm{P}<0.001)$ the time (h) to produce $50 \%$ of $A$ and reduced $(\mathrm{P}<0.001)$ the time $(\mathrm{h})$ to produce $95 \%$ of $A$. There were significant $(\mathrm{P}<0.001)$ cultivar and treatment interaction effects for $A$, time (h) to produce $50 \%$ of $A$ and $\mu$ at 3,6 and $12 \mathrm{~h}$ of incubation. 
Table 2 The kinetics of gas production of different cultivars of barley grain incubated with rumen fluid ( $\mathrm{n}=3 /$ cultivar $)$

\begin{tabular}{|c|c|c|c|c|c|c|}
\hline & \multicolumn{6}{|c|}{ Gas production kinetics } \\
\hline & $A$ & $50 \%$ & $95 \%$ & $\mu_{3}$ & $\mu_{6}$ & $\mu_{12}$ \\
\hline \multicolumn{7}{|l|}{ Cultivars } \\
\hline Hega & $402.6^{\mathrm{bcd}}$ & $5.9^{\mathrm{a}}$ & $56.6^{\mathrm{b}}$ & $7.4^{\mathrm{c}}$ & $5.3^{\mathrm{c}}$ & $3.7^{\mathrm{c}}$ \\
\hline Prosa & $393.1^{\mathrm{ab}}$ & $5.9^{\mathrm{a}}$ & $51.0^{\mathrm{ab}}$ & $7.2^{\mathrm{bc}}$ & $5.1^{b c}$ & $3.6^{\mathrm{bc}}$ \\
\hline Vanesa & $397.9^{\mathrm{abcd}}$ & $6.2^{\mathrm{a}}$ & $52.4^{\mathrm{ab}}$ & $6.8^{\mathrm{ab}}$ & $4.8^{\mathrm{ab}}$ & $3.4^{\mathrm{ab}}$ \\
\hline Viva & $394.9^{a b c}$ & $6.6^{\mathrm{b}}$ & $51.3^{\mathrm{ab}}$ & $6.3^{\mathrm{a}}$ & $4.5^{\mathrm{a}}$ & $3.2^{\mathrm{a}}$ \\
\hline $5-8602$ & $404.9^{\text {de }}$ & $6.2^{\mathrm{ab}}$ & $53.0^{\mathrm{ab}}$ & $6.7^{\mathrm{ab}}$ & $4.8^{\mathrm{ab}}$ & $3.4^{\mathrm{ab}}$ \\
\hline Cecilla & $402.8^{\text {cde }}$ & $6.5^{\mathrm{b}}$ & $48.9^{\mathrm{ab}}$ & $6.3^{\mathrm{a}}$ & $4.5^{\mathrm{a}}$ & $3.2^{\mathrm{a}}$ \\
\hline Esterel & $410.8^{\mathrm{e}}$ & $6.1^{\mathrm{ab}}$ & $48.4^{\mathrm{ab}}$ & $6.7^{\mathrm{ab}}$ & $4.7^{\mathrm{ab}}$ & $3.33^{\mathrm{ab}}$ \\
\hline Angora & $389.9^{\mathrm{a}}$ & $6.0^{\mathrm{ab}}$ & $45.8^{\mathrm{a}}$ & $6.5^{\mathrm{ab}}$ & $4.3^{\mathrm{ab}}$ & $3.25^{\mathrm{ab}}$ \\
\hline s.e.m & 1.98 & 0.12 & 2.19 & 0.15 & 0.11 & 0.074 \\
\hline \multicolumn{7}{|l|}{$\mathrm{HCOH}$ Treatment } \\
\hline Untreated & 424.5 & 5.5 & 55.5 & 7.8 & 5.5 & 3.9 \\
\hline Treated & 374.8 & 6.9 & 46.4 & 5.7 & 4.0 & 2.9 \\
\hline s.e.m & 0.99 & 0.06 & 1.10 & 0.07 & 0.05 & 0.037 \\
\hline \multicolumn{7}{|l|}{ Treatment effects } \\
\hline Cultivars & $* * *$ & $* * *$ & $*$ & $* * *$ & $* * *$ & $* * *$ \\
\hline Treatment & $* * *$ & $* * *$ & $* * *$ & $* * *$ & $* * *$ & $* * *$ \\
\hline Interaction & $* * *$ & $* * *$ & NS & $* *$ & $* *$ & $* *$ \\
\hline
\end{tabular}

$A$-Total gas production (mL); $50 \%$ - time (h) to produce $50 \%$ of total gas production; $95 \%$ - time (h) to produce $95 \%$ of total gas production; $\mu_{3}, \mu_{6}$ and $\mu_{12}$ - Gas production rate (\%) at 3,6 and $12 \mathrm{~h}$ of incubation, respectively

${ }^{\mathrm{a} b \mathrm{c}}$ Within columns, means with common superscripts do not differ $(\mathrm{P}>0.05)$ and $*$ signifies $\mathrm{P}<0.05 ; * * \mathrm{P}<0.01$;

*** $\mathrm{P}<0.001$; NS - Non significant $\mathrm{P}>0.05$; s.e.m - Standard error mean

\section{Discussion}

The CP levels of the barley cultivars used in this experiment were considerably higher than those of barley cultivars reported by Ghorbani \& Hadj-Hussaini (2002) who showed that the CP levels of 10 barley cultivars ranged from 90 to $117 \mathrm{~g} / \mathrm{kg} \mathrm{DM}$. This might have been due to differences between cultivars and growing conditions. Bradshaw et al. (1992) have shown that environmental and seasonal variations can affect the chemical composition of barley cultivars. On the other hand, CP levels of the cultivars were similar to those reported by Ortega-Cerrilla et al. (1999b) and Yu et al. (2003).

The NDF and ADF levels of barley cultivars were consistent with those reported by Ghorbani \& HadjHussaini (2002) and Woods et al. (2003). Starch content of barley used in the present experiment was considerably higher than that reported by Ljøkjel et al. (2003), but similar to that obtained by Shivus \& Gullord (2002) who found that the starch content of five barley cultivars ranged from 587 to $641 \mathrm{~g} / \mathrm{kg}$ DM. Ether extract and ash levels of the barley cultivars were in agreement with the findings of Shivus \& Gullord (2002).

Due to lower gas production rates the cultivars, Viva and Cecilla, showed the longest times to produce $50 \%$ of total gas production. However, there is no information available relating in vitro characteristics of barley fermentation to animal performance, though there is some information available on in situ degradation characteristics of barley to animal performance. Givens et al. (1993) suggested that barley cultivars with slower rates of degradation might be superior in ruminant nutrition to those with faster rates because as the rate of degradation of a grain increases, susceptibility to digestive problems such as metabolic acidosis, bloat and grain overload would be expected to increase. Therefore, the cultivars, Viva and Cecilla, with their lower fermentation rates might be recommended to minimize metabolic disorders in ruminants.

Grinding of barley grain to pass through a $1 \mathrm{~mm}$ screen could have masked the beneficial effects of formaldehyde treatment since grinding greatly enhances the surface area available for microorganisms. At the early stages of incubation there were no apparent differences in gas production between cultivars, which might be related to the effect of grinding. 
Treatment of barley grain with $\mathrm{HCHO}$ at a level of $30 \mathrm{~g} \mathrm{HCHO} / \mathrm{kg}$ barley $\mathrm{CP}$ did confer some protection against fermentation in vitro, as reflected in the estimated parameters derived from the in vitro gas production. HCHO treatment of barley grain might have reduced the available protein to microorganism directly and reduced the available starch to microorganisms indirectly. McAllister et al. (1990a) conducted electron microscopy studies on HCHO treated barley subjected to in vitro incubation with rumen fluid. The HCHO treatment reduced microbial degradation of barley starch, and McAllister et al. (1990a) concluded that this was due to the protective effect of formaldehyde on protein degradation. Reducing the digestibility of the protein matrix of endosperm inhibited the access of bacteria to embedded starch granules (McAllister et al., 1990b). The reduction in total gas production $(A)$ may be due to a reduction in the available substrate for microorganisms which would reduce the time $(\mathrm{h})$ required by the microorganisms to produce $95 \%$ of total gas produced. The reduction in gas production rate $(\mu)$ during early incubation might have resulted in an increase in the time (h) to produce $50 \%$ of the total gas production. A reduced rate or increased lag time could be due to either alteration of the fermentable carbohydrate or the presence of an inhibitory residue of formaldehyde in the substrate.

Protein fermentation does not contribute greatly to gas production, and should not be a limiting factor in in vitro incubation studies since there is enough $\mathrm{N}$ in the incubation buffer. Therefore, most of the effects of formaldehyde should be expected to originate from a reduction in the protein fermentation and degradation, which should reduce starch availability to ruminal microbes. It might be interesting to perform a follow-up study looking at the intestinal digestibility of protein and starch fractions of the formaldehyde treated barley grains.

Plant characteristics, particularly ruminal digestibility, are known to be strongly affected by genotypeenvironmental interactions (Reynolds et al., 1992). In this experiment the barley cultivars were grown only over a single growing season, and at a single location. This is one of the shortcomings of this study to give more conclusive information on the effect of cultivars on in vitro gas production.

\section{Conclusion}

Cultivars and HCHO treatment had a significant effect on gas production kinetics of barley grains. HCHO treatment may provide the opportunity to manipulate the site of digestion of DM. It seems to be possible to reduce some of the nutritional and health problems in the rumen through the selection of cultivar and the utilizing the $\mathrm{HCHO}$ treatment. This experiment also showed that the gas production method is a useful method to determine the effect of cultivars and chemical treatment on DM fermentation in vitro.

More research is required to determine the relationship between fermentation in vitro characteristics and animal performance. There is also a need to determine the effect of environment on the chemical composition and in vitro fermentation characteristics of barley cultivars.

\section{References}

AOAC, 1990. Official methods of analysis (14 ${ }^{\text {th }}$ ed.). Association of Official Analytical Chemists, Inc., Washington, D.C., USA. pp. 66-88.

Bradshaw, W.L., Hinman, D.D., Bull, R.C. \& Everson, D.O., 1992. Steptoe vs Klages barley varieties and processing methods on feedlot steer nutrient digestibility, carcass characteristics, and performance. West. Sec. Am. Soc. Anim. Sci. 43, 548-550.

Depeters, E.J., Getachew, G., Fadel, J.G., Zinn, R.A., Taylor, S.J., Pareas, J.W., Hinders, R.G. \& Aseltine, M.S., 2003. In vitro gas production as a method to compare fermentation characteristics of steam flaked corn. Anim. Feed. Sci. Technol. 105, 109-122.

EEC, 1972. Determination of starch. Polarimetric method. Official Journal of European Communities, Brussels, Belgium. p. 6.

Faichney, G.J. \& Davies, H.L., 1973. The performance of calves given concentrate diets treated with formaldehyde. Aust. J. Agric. Res. 24, 613-621.

Fluharty, F.L. \& Loerch, S.C., 1989. Chemical treatment of ground corn to limit ruminal starch digestion. Can. J. Anim. Sci. 69, 173-180.

France, J., Dhanoa, M.S., Theodorou, M.K., Lister, S.J., Davies, D.R. \& Isaac, D., 1993. A model to interpret gas accumulation profiles associated with in vitro degradation of ruminant feeds. J. Theor. Biol. 163, 99-111. 
Ghorbani, G.R. \& Hadj-Hussaini A., 2002. In situ degradability of Iranian barley grain cultivars. Small Rumin. Res. 44, 207-212.

Givens, D.I., Clark, P., Jacklin, D., Moss, A.R. \& Savey, C.R., 1993. Nutritional aspects of cereal, cereal grain by products and cereal straw for ruminants. HGCA research Review No. 24, Home Grown Cereals Authority, Hamlyn house, Highgate Hill, London, UK. pp. 1-180.

Ljøkjel, K., Harstad, O.M., Prestløkken, E. \& Skrede A., 2003. In situ digestibility of protein in barley grain (Hordeum vulgare) and peas (Pisum sativum L.) in dairy cows: influence of heat treatment and glucose addition. Anim. Feed Sci. Technol. 107, 105-116.

McAllister, T., Cheng, K.J., Rode, L.M. \& Buchanan-Smith, J., 1990a. Use of formaldehyde to regulate digestion of barley starch. Can. J. Anim. Sci. 70, 581-589.

McAllister, T.A., Cheng, K.J., Rode, L.M. \& Roffler, R.E., 1990b. Effect of formaldehyde treatment of barley on in situ dry matter, starch and protein disappearance. Can. J. Anim. Sci. 70, 1159 (Abstr.).

Menke, K.H., Steingass, H. \& Fritz, D., 1988. Estimation of the energetic feed value obtained from chemical analysis and in vitro gas production using rumen fluid. Anim. Res. Dev. 28, 7-55.

Nocek, I.E. \& Tamminga, S., 1991. Site of digestion of starch in the gastrointestinal tract of dairy cows and its effect on milk yield and composition. J. Dairy Sci. 74, 3598-3629.

Opatpatanakit, Y., Kellaway, R.C., Lean, I.J., Annison, G. \& Kirby, A., 1994. Microbial fermentation of cereal grains in vitro. Aust. J. Agric. Res. 45, 1247-1263.

Ørskov, E.R., 1986. Starch digestion and utilization and utilization in ruminants. J. Anim. Sci. 63, 16241633.

Ortega-Cerrilla, M.E., Finlayson, H.J. \& Armstrong, D.G., 1999a. Protection of starch in barley against rumen degradation by glutaraldehyde and formaldehyde as assessed by dacron bag technique. Anim. Feed Sci. Technol. 77, 83-90.

Ortega-Cerrilla, M.E, Finlayson, H.J. \& Armstrong, D.G., 1999b. The effect of chemical treatment of barley on starch digestion in ruminants. Anim. Feed Sci. Technol. 77, 73-81.

Pearse, E.S. \& Hartley, H.O., 1966. Biometrika Tables for Statisticians. Vol.1. Cambridge University Press, UK. 270 pp.

Pedersen, J.F., Milton, T. \& Mass, R.A., 2000. Crop quality and utilization. A twelve-hour in vitro procedure for sorghum grain feed quality assessment. Crop Sci. 40, 204-208.

Reynolds, W.K., Hunt, C.W., Eckert, J.W. \& Hall, M.H., 1992. Evaluation of the feeding value of barley as affected by variety and location using near infrared reflectance spectroscopy. Proc. West. Sect. Am. Soc. Anim. Sci. 43, 498-501.

Ross, G.J.S., 1987. Maximum likelihood program. Rothamstad Experimental Station, Harpenden, UK.

Shivus, B. \& Gullord, M., 2002. Effect of chemical content and physical characteristics on nutritional value of wheat, barley and oats for poultry. Anim. Feed Sci. Technol. 102, 71-92.

Statistica, 1993. Statistica for windows release 4.3, StatSoft, Inc. Tulsa, OK, USA.

Streeter, M.N., Hill, G.M., Wagner, D.G., Hibbert, C.A. \& Owens, F.N., 1993. Chemical and physical properties and in vitro dry matter on starch digestion of eight sorghum grain hybrids and maize. Anim. Feed Sci. Technol. 44, 45-48.

Van Soest, P.J., 1963. The use of detergents in the analysis of fibrous feeds. II. A rapid method for the determination of fiber and lignin. J. AOAC. 46, 829-835.

Van Soest, P.J., Robertson, J.D. \& Lewis, B.A., 1991 Methods for dietary fibre, neutral detergent fibre and non-starch polysaccharides in relation to animal nutrition. J. Dairy Sci. 74, 3583-3597.

Woods, V.B., O'Mara, F.P. \& Moloney, A.P., 2003. The nutritive value of concentrate feedstuffs for ruminant animals: Part I: In situ ruminal degradability of dry matter and organic matter. Anim. Feed Sci. Technol. 110, 111-130.

Yu, P., Meier, J.A., Christensen, D.A., Rossnagel, B.G. \& McKinnon, J.J., 2003. Using the NRC-2001 model and the DVE/OEB system to evaluate nutritive values of Harrington (malting-type) and Valier (feed-type) barley for ruminants. Anim. Feed Sci. Technol. 107, 45-60. 